\title{
Ergonomic risks in mining companies: a study in Paraiba/Brazil
}

\author{
Morais, S. F. A. . , Santos, A. C. Q. ${ }^{a}$, Gonçalves, W. P. ${ }^{a}$, Albuquerque Neto, H. C. ${ }^{\text {, }}$ and Sanjinéz \\ Argandoña, E. J. ${ }^{\mathrm{c}}$ \\ ${ }^{a}$ Department of Industrial Engineering, Federal University of Campina Grande, Av: Aprígio Veloso, 882 \\ Bodocongó CEP 58109-970. Campina Grande-PB Brazil, e-mail: suelyn.morais@hotmail.com \\ ${ }^{\mathrm{b}}$ Department of Industrial Engineering and Management, University of Porto, Dr. Roberto Frias S/N 4200-465, \\ Porto/Portugal,e-mail: helio.neto@fe.up.pt \\ ${ }^{\circ}$ Department of Food Engineering, Federal University of Grande Dourados, Dr. Roberto Frias S/N 4200-465, \\ Porto/Portugal, e-mail: elianaargandona@ufgd.edu.br
}

\begin{abstract}
The growing concern for the welfare of workers in the work environment, the importance of widespread use of ergonomics in the different sectors of industry. Yet most corporate practices that work with rudimentary or great need for human handling of materials is not fully in line with the ergonomic aspects. Given this, this article aims to identify ergonomic hazards in mining to later propose improvements in the process. After a series conducted plant visits, found that workers are exposed to various ergonomic risks, which entails the need for new healthy practices in the workplace. Finally, a series of proposals are submitted in order to avoid possible occupational diseases.
\end{abstract}

Keywords: Risks, solution, health

\section{Introduction}

Mining is one of the basic sectors in the present economy of a country that help accurately and consistently well-being and improved quality of life for current and future generations, it is paramount to the development of an egalitarian society, provided it is carried out with social responsibility, always involving the precepts of sustainable development.

However, it has been observed that the man versus work at times, have a negative effect, because in many cases, the risks that operators are exposed in the workplace. Furthermore, the analysis of environmental conditions in mining, is an extremely important factor for hygiene, health and safety of workers. In this light the purpose of this paper is to analyze the ergonomic job of a mining industry in the state of Paraiba, Brazil, to the identification of ergonomic risks and then implement the improvements in order to provide a greater good being of workers and re- duce the occurrence of absenteeism caused by accidents and occupational diseases.

\section{Materials and Methods}

In keeping with the purpose of this article, we sought viable solutions to improve the ergonomic aspects of the company of the target of study. For this choice, we considered the feasibility of the researchers and knowledge with staff and manager. The practical procedures also include the following assumptions: a literature review, observations "in situ" and "in loco" application of semi-structured questionnaires to employees based on verification of the critical job of the workers, highlighting the potential disease-causing occupational. Finally, there is the implementation of preventive, mitigatory and compensatory measures in order to minimize and/or eliminate the impact of possible negative impacts from the workers of the enterprise. 


\section{Analysis of results}

\subsection{Brief description of the company}

The mining company began operations in 1986 and currently has a staff of 60 employees working in two shifts of four hours, Monday to Friday, plus the ability to use overtime. The company works with processing of limestone, as the final product resulting calcium carbonate $(\mathrm{CaCO} 3)$. The daily production is approximately 140 tons of $\mathrm{CaCO} 3$ and its final product is destined for the paint industry, soap, rubber and agricultural application.

In the process under study there was a constant presence of dust from the fragmentation of the limestone, which can cause the appearance of pneumoconiosis (lung disease caused by inhaling fragments of mineral materials). In contrast, the company provides its workers some Personal Protective Equipment (PPE), which are: masks, goggles and ear protectors.

\subsection{Ergonomic Task Analysis}

Initially there was the schooling of all workers who work in the crushing process, which are all males having on average 33 years of age, low education level (Middle School). Was analyzed by the crushing process in order to identify practices potentially harmful to human health, such as:

- During the work crushers perform major effort in upper and lower limbs, without any kind of rest or breaks during the workday. Given this, there were reports of employees on the occurrence of pain and/or discomfort in the regions of the arms, hands, spine and legs. These discomforts can develop into serious health problems such as disturbances in blood circulation of the limbs, muscle fatigue and decreased manual dexterity;

- The movement of workers has negative repercussions in the health of us, as do most of the works constantly flexing the spine by lifting loads greater than 30 pounds. This survey of large excess can cause serious diseases such as back pain and disc herniation.

Next, we sought to characterize the work environment as a whole, checking the main points ergonomic, these being:
- Brightness Environment: It was found that crushing the environment has enough natural light to play in the process;

- Thermal environment: this environment is wide variation in temperature during the workday. Several workers reported that the temperature a change is an unfavorable factor in the workplace, leaving them stressed. This causes a great loss of productivity by the employee, in addition to an irritation that can lead to psycho-mental problems;

- Sound Environment: It was observed that workers wear PPE headset, yet this proves to be insufficient to ensure protection to the worker, as Crusher rattle sound above $85 \mathrm{~dB}$, which is the maximum recommended by the Brazilian labor ministry for a maximum exposure eight hours daily. This noise can cause over time ear disorders such as tinnitus, recruitment (sensitivity to loud sounds) and hearing loss partial or complete.

\section{Conclusions}

Initially there was the schooling of all workers who work in the crushing process, which are all males having on average 33 years of age, low education level (Middle School). Was analyzed by the crushing process in order to identify practices potentially harmful to human health, such as:

Using knowledge of ergonomics in organizations working methods allows healthier, confirming the well-being of workers and generate more motivation and cooperative workplace. Moreover, efficient ergonomic practices minimize risk of occupational accidents and occupational discomfort, which cause a consequent increase in productivity.

Thus, this article attempts to make a diagnosis where ergonomic problems were observed related to the position of workers, since these are vulnerable to possible occupational diseases.

While providing PPE to their employees, it is essential that improve and optimize the process of worker safety in the company studied. In short, it is proposed that the company adopt some measures to mitigate / minimize the negative impacts on existing crushing process, improving working conditions. Such measures are:

- The use of most modern crushers, where noise is less intense; 
- Adoption of gymnastics during certain periods of the workday, in order to prevent occupational diseases;

- Create training programs, courses and lectures in order to adopt ergonomic working methods, minimized the risks to health;

- Development and implementation of risk maps in the different sectors of the company.

It should be noted that all these measures must be in line with company strategy, so that they are implemented efficiently, panning the desired effects. Finally, the discussion undertaken in this study raises a discussion of the current working conditions of miners and the impact it has on your health.

\section{References}

[1] H. A. Couto, Ergonomia aplicada ao trabalho: em 18 lições, Belo Horizonte: Ergo 2002. Newman and E.T. Liu, Perspective on BRCA1, Breast Disease 10 (1998), 3-10.

[2] F. Fialho and N. Santos, Manual de Análise Ergonômica no Trabalho. Genesis, 1995.

[3] F. Guérin; A. Laville; F. Daniellou; J. Duraffourg and A. Kerguele, Compreender o Trabalho para Transformá-lo: a Prática da Ergonomia, São Paulo, Blücher Ltda, 2001

[4] M. M. Meyer, Gestão ambiental no setor mineral: um estudo de caso, Master dissertation, Federal University of Santa Catarina, 2000. 